\title{
THE ROLE OF RECORDING AND REPORTING PROCESS OF BASIC ACCOUNTING IN SMALL MEDIUM ENTREPRISES OF OMAH DUREN SURABAYA
}

\author{
Lucya Erlinda Sonia *) \\ Stefanie Gianto **)
}

\begin{abstract}
Financial management is a problem that is quite difficult for Small and Medium Enterprises (SMEs) in Indonesia. The lack of awareness and knowledge of SMEs owner regarding the accounting process considered as the root causes of their financial management difficulties. Based on that, researcher aims to help one of SMEs in Surabaya which is Omah Duren Surabaya, in order to know about the process of recording and reporting a SME, then find a way to improve it in a diligent way. Researcher uses interviews, observations and documents sheets to analyze and knowhow Omah Duren business process. The information that gained from Omah Duren owner and transaction data, as well as direct observation in recording and reporting activities is one of researcher data sources. Researcher concluded that Omah Duren SME's still not performing the simple accounting process in accordance with generally accepted. Therefore, researcher provide a recommendations in helping them in recording and reporting their financial effectively and efficiently. This research will also discuss the role of recording and reporting that is generally accepted for SMEs.
\end{abstract}

Keywords: SME, Accounting, Financial Statement

\section{INTRODUCTION}

\subsection{Research Background}

The booster of a country's economic development can start from the Small and Medium Enterprises (SMEs) in the country itself. SME is a term that refers to a type of small business that has a net worth of 50 million excluding land and building places of business. Small scale of economics activity with the small business activity (Presidential Decree No. 99 of 1998). People who open store with one or more people, creative and craft, industrial processing and manufacturing industries, as well as small to medium-scale factories also entered in the class of MSME according to UU No. 20 of 2008.

Table 1 MSME Classification

\begin{tabular}{|l|l|l|l|}
\hline Business & Net Worth (IDR) & Sales (IDR) & Number (Unit) \\
\hline Micro & 50 Million & 300 Million & 3.385 .851 \\
\hline Small & $>50-500$ Million & $>300$ Million - 2,5 Billion & 283.022 \\
\hline Medium & $>500$ Million - 10 Billion & $>2,5$ Billion - 50 Billion & \multirow{2}{*}{26.322} \\
\cline { 1 - 2 } Big & $>10$ Billion & $>50$ Billion & \\
\hline
\end{tabular}

According to Urata (2000), the position of SMEs is divided into five, namely:

a. Main players in economic activities in various sectors.

b. The largest provider of SMEs employment is the largest business in a nation, it is likely that SMEs need a lot of manpower in running their business.

c. Players are important in the development of regional economic activities and community empowerment.

d. Creator of new markets and innovation. Inevitably, an innovation also emerges from small and medium-scale businesses, because of the high competition of similar businesses. To start new businesses, SMEs owners will strive to bring up something new with limited resources. 
e. Contributing in maintaining payments balance through its contribution in exporting goods. This can happen if the SMEs are already able to export abroad or go-international.

Indonesian Finance Minister, Sri Mulyani Indrawati said Micro, Small and Medium Enterprises (MSMEs) are the backbone of Indonesia's economy (Primadhtya, 2016). According to BPS data, the number of MSMEs in Indonesia is 57.9 million units or 99.99 percent from total number of national business actors. MSMEs contribute to employment of 96.99 percent. The MSEs employs consists of over 107.6 million of Indonesians and contributes 60.6 percent of Indonesia's GDP. (Suroto, 2016). SME growth also occurs in the capital of East Java province, Surabaya. SMEs in Surabaya has grown by more than 300 percent. Currently, Surabaya already has around 3,000 SMEs from total SMEs in 2010 of 92 SMEs (Afrianto, 2016). This cannot be separated from the role of Surabaya's Mayor, Tri Rismaharini, who encourages Surabaya people to be an entrepreneur (Chandra, 2016). By doing that, it is expected that Surabaya's economy will be better and unemployment rate can be declined. From 110 million Indonesia people, about 107 million people are included in the structure of Micro, Small and Medium Enterprises or MSMEs. This means that the portion of people working as MSME reaches about 97.3 percent (Marta, 2016). The development of SME's become serious concern from various sectors, business owners to local governments. SME's faced various problems that can hinder a business development like capital limited, low quality of resources and marketing promotion (Pamungkas, 2015). In addition, most of business owners also had limited business knowledge so they faced difficulties in adapting technology and financial management.

The problem of financial management becomes a complicated issue, as most SMEs owners have limited knowledge of accounting, so they do not know how to manage their finances. As a result, most small entrepreneurs (MSMEs) in Indonesia do not organize and use accounting information in their business management (Pinasti, 2007). The American Institute of Certified Public Accounting (AICPA) in Harahap (2003) defined that accounting as the art of recording, classifying and summarizing with certain ways of monetary measure, transactions, and events that are generally financial in nature include interpreting the results. This recording and reporting activity can generate accounting information, which is used by SMEs owners to evaluate business performance and become the basis of decision making in various matters related to their business. The inability of SMEs in managing their finances is very influential on the progress of his business. The worse is accounting becomes something that is ignored, because for most SME owners, accounting is difficult to understand. As in the research Ediraras (2010), some SMEs have not done accounting caused by several things, namely; 1). some people assume because the business they run is a family business and not so big then they just think that the accounting is so important. 2). Because of the lack of knowledge and competencies of someone related to accounting. 3). Fund used for business often mixed with own funds, or directly used to buy goods without having time to do accounting first. 4). Accounting is too complicated, also because the time is already preoccupied for the job, so it is very difficult to set aside time to compile the accounting. 5).There are no fix income.

\subsection{Research Problem}

Based on the reason above, researchers interested to examine how the recording and reporting activity in Omah Duren and how to apply a simple recording and reporting process that can be done by Omah Duren.

\subsection{Research Purpose}

Researcher tries to give explanation by evaluating and developing theories related to the role of recording and reporting of basic accounting in Omah Duren Surabaya. This research has an applied research benefit because researcher provides recommendations regarding the recording and reporting system of Omah Duren issues. 


\section{THEORETICAL FRAMEWORK}

\subsection{Theoretical Framework}

\subsubsection{SMEs}

According to UU No 20, 2008, Small and Medium Enterprises (SMEs) can be defined as a business which has Rp. 50 Million until Rp10 Billion of net worth, excluding land and business building, or has Rp. 300 Million until Rp 50 Billion of annual Sales. Those net worth amount should be accountable to the business interested parties. Business owners always prevent its business declining, therefor the role of recording and reporting is very important in showing stakeholder about their economy activities and "the real business situations" (Warren, Reeve, Duchac, Suhardianto, Kalanjati, Jusuf, \& Djakman, 2014).

\subsubsection{Accounting}

Accounting is an information system that generates reports to interested parties about the economic activity and conditions of a business (Warren, Reeve, Duchac, Suhardianto, Kalanjati, Jusuf, \& Djakman, 2014). Transaction becomes the beginning of every accounting process information system begins. According to Warren, Reeve, Duchac, Suhardianto, Kalanjati, Jusuf, \& Djakman (2014), business transaction is an event or economic condition that directly changes the company's financial condition or the outcome of its operations. Transactions in a business activity will be recorded and reported in the financial statements. The financial reporting activities usually includes financial statements which consist of balance sheet (financial position statement), income statement, cash flow statement, changes in euity statement report and notes on financial report (Ikatan Akuntan Indonesia, 2009).

According to the Financial Accounting Standards Board, financial statements aims to provide information about the financial position, its business performance, and financial position statement of a company that gives consideration in making economic decisions. Financial statements users consist of capital market stakeholders, product/service markets, government, and internal company. In addition, a business also needs to pay attention to the expenses on its production activities, especially the Cost of Manufactured Sales. According to the Indonesian Institute of Accountants, the cost of manufactured sales consist of direct material, wages and indirect production costs, processing in the calculation of beginning and ending balance of manufacturing process. It may be reported in the Cost of Manufactured Goods Report (Mulyadi, 2010) to show the use of fees in specific period.

\section{RESEARCH METHOD}

This research is developed based on two research question which is main research question and mini research question. Therefore, in order to answer main research question, researcher chooses an interviews, document analysis, and direct observation as the research methods. Researcher uses interview to obtain the answer about the role and the impact of recording and reporting in Omah Duren Surabaya.

Table 2 Details of Interview

\begin{tabular}{|c|c|c|c|c|}
\hline Position & Participants & Hours & Criteria & Topic of Interviews \\
\hline Owner & 1 & $5-7$ & Owner & $\begin{array}{c}\text { Current practices of Omah } \\
\text { Duren accounting process }\end{array}$ \\
\hline
\end{tabular}

In addition, researcher also analyzes the accounts that can be used in the recording and reporting process of Omah Duren. According Sugiyono (2012) document study is a complement of the use of observation methods and interviews in qualitative research. The credibility of this qualitative research results will be higher if researcher uses document analysis. Furthermore, researchers also used observation methods to observe the production site and recording process of SMEs Omah Duren, so it can help explain the process of recording and reporting done.. 
Observation is a systematic observation and recording of elements that appear in a symptom on the object of research (Nawawi \& Martini, 1992)

Table 3 Document List.

\begin{tabular}{|l|c|}
\hline \multicolumn{1}{|c|}{ Document Types } & Hours \\
\hline Transaction Receipt Proofs & 7 \\
\hline Journal, Books, Article & 13 \\
\hline $\begin{array}{l}\text { Omah Duren Social Media and Question } \\
\text { Answer sessions through Whatsapp channel }\end{array}$ & 7 \\
\hline \multicolumn{1}{|c|}{ Total } & 27 \\
\hline
\end{tabular}

Table 4 Details of Observation

\begin{tabular}{|c|c|c|c|}
\hline Location & Hours & Criteria & Topics \\
\hline Production House & $1-3$ & Udur-Udur Production Location & Accounting Cycles \\
\hline
\end{tabular}

\section{RESEARCH RESULT AND ANALYSIS}

\subsection{Omah Duren Surabaya Profile}

Omah Duren Surabaya business started in 2014 by Mrs. Trisna as the owner of Omah Duren. As suggested by the name, Omah Duren sells products from processed durian, which is durian juice with the product name of Udur-Udur. At that time, Mrs. Trisna started her business by renting a booth at Manyar, Surabaya, using a cart to sell her product. The owner sells her product in Manyar area, Surabaya with various menu variants, namely Duren Juice, Duren Soup, Kelapa Muda Duren, Ketan Duren and grilled sausage. In 2015, Omah Duren no longer do personal selling, but chose to market their products to several outlets of Lapis Kukus Pahlawan in Surabaya and Sidoarjo and also entrusted to Sentra SMEs Merr and Sentra SMEs Siola. Not only offline sales, but Omah Duren began to expand to online sales. Through the existing social media, buyers do not have to come to the outlet, but can directly order to the seller. Until 2017, Omah Duren continues to increase sales through exhibition and promotion activities through social media. The increasing on sales impact on Omah Duren's income. Within a month, Omah Duren earned an average gross sales of 16 million rupiah to 26 million rupiah, or approximately 312 million rupiah per year, excluding online orders.

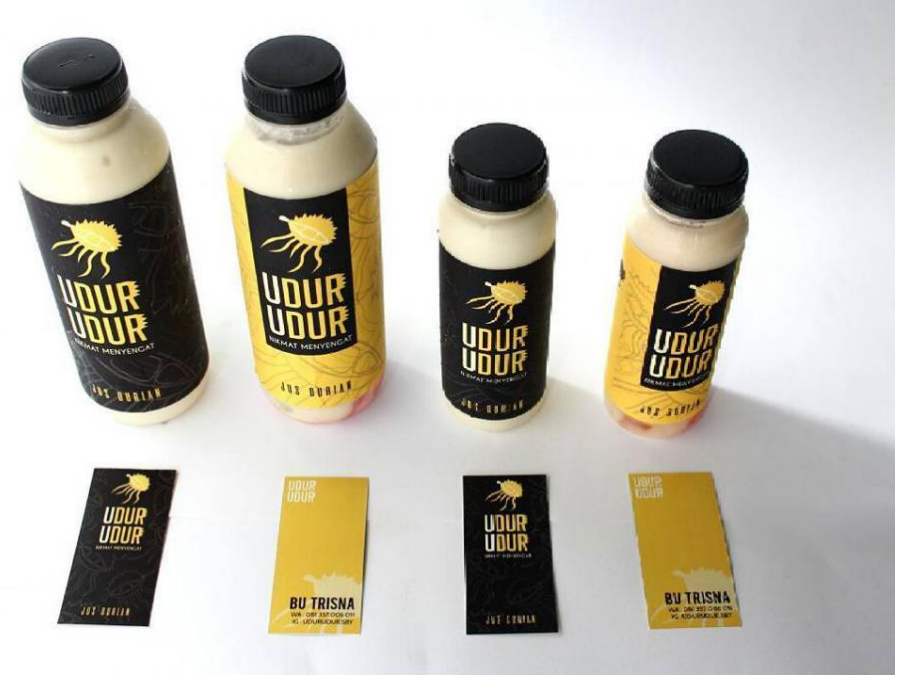

Picture 1 Udur-Udur Omah Duren Surabaya

\subsection{Pricing}

The selling price of product is determined at the beginning of business long time ago and surprisingly that price is still used until now. The profit is come from the price of durian. Here are 
the results of interviews with Omah Duren owner about the profits of sales: "The profits is fluctuative, the main ingredient price is up and down, especially the price of durian. The other expenses are relatively stable, its increasing but not too much. For example, durian meat price is $R p .55 .000$, now it is Rp. 100.000, the normal price is at Rp. 65.000 for a kilo." But unfortunately, durian fruit is not always exists every month, so the durian price will rise more during November to January, and the price will rise again during May to June. The price of durian is very influential on the profits of durian processing products selling of Omah Duren. Like stated by the owner of Omah Duren,: "So the profit is in durian meat. When the price is normal, I can get enough profit, but if not in season (durian), the price of durian will rise, so I will get less profit. So, I don't have to get much profit as long as I still get enough. If (durian price) Rp. 65-70.000, the profit can be 100\%, but if the price of durian rising (Rp. 100.000,-), the profit can be below 50\%, but its still profit. Thus, if the price is Rp. 130.000, I still get $20 \%$ profit. That's the highest price of durian. So the price of the product is fixed when the durian is more expensive."

Tabel 5 Profit Comparison Based on Durian Price

\begin{tabular}{|c|c|c|c|c|}
\hline Profit (\%) & Price & Durian (per kilo) & Expenses & Profit \\
\hline $120 \%$ & Rp15.000 & Rp55.000 & Xxx & Rp8.181 \\
\hline $100 \%$ & Rp15.000 & Rp65.000 & Xxx & Rp7.500 \\
\hline $50 \%$ & Rp15.000 & Rp100.000 & Xxx & Rp5.000 \\
\hline $20 \%$ & Rp15.000 & Rp130.000 & Xxx & Rp2.500 \\
\hline
\end{tabular}

\subsection{Production Process}

After the order is taken, the owner is ready to make the production process. Production process of Udur-Udur starts from the purchase of raw materials to suppliers and to stalls. Raw materials consist of durian fruit meat, milk, sugar, drinking water and bubble. For durian and bubble as raw materials are ordered by the owner from different suppliers, and ordered a few days before the production process, usually ordered on Sunday. Owner buy milk, sugar and water when the stock is began limited at a nearby store. In addition preparing the raw materials, the owner also purchased bottles at a subscription store. Each week, the owner buys about 140 units of $250 \mathrm{ml}$ packaging bottle and 104 units of $500 \mathrm{ml}$ packaging bottles.

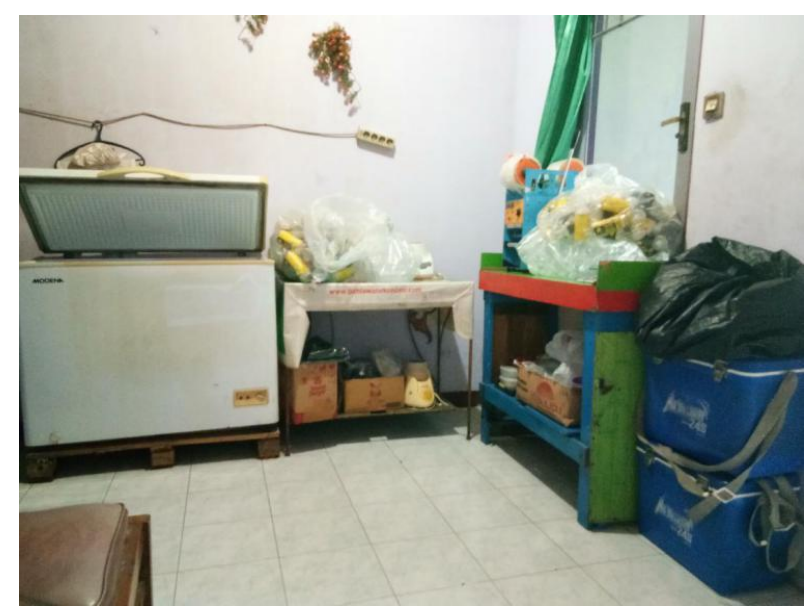

Picture 2 Omah Duren Production Places 


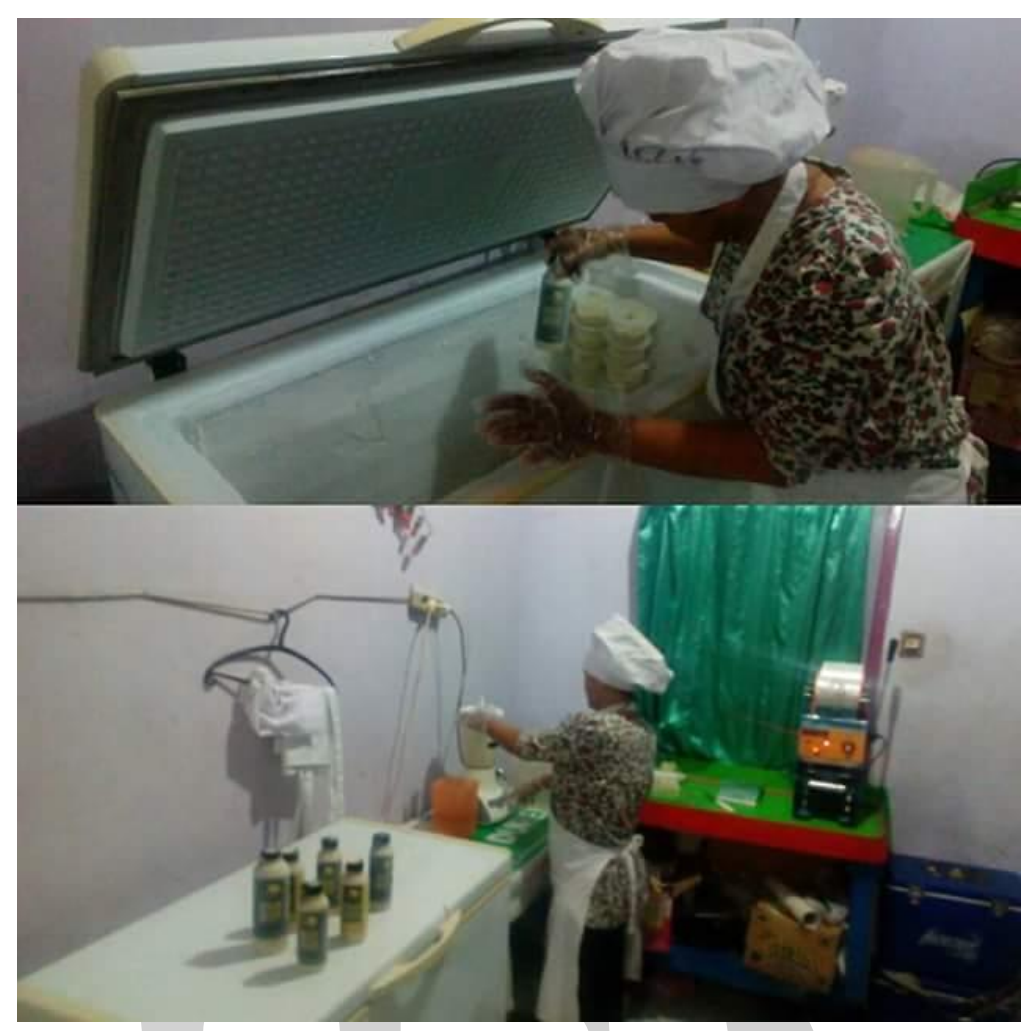

Picture 3 Omah Duren Production Process

The owner also performs sticker printing for packaging bottles. Each week, the owner prints stickers of 21 sheets of A3 sticker paper in the printing press. Out of 21 pieces, it is then divided into 14 sheets for the size of $500 \mathrm{ml}$, and 7 sheets for the size of $250 \mathrm{ml}$. After preparing the material, the owner performs the blending process of durian fruit, sugar, milk, drinking water until it becomes durian juice. Blending process is using two blender machines. The finished juice is ready to be inserted into the bottle of various sizes. Then, additional bubble into the Lite bottle before the durian juice is poured. The bottle that already filled with durian juice is closed, then juice left on the edge of the bottle is cleaned. After cleaning process, all the bottles of Udur-Udur are placed into the freezer. Udur-Udur requires special conditions for storage to last long, in example stored in the freezer for two months last. This also causes the owner to buy a freezer as a place of product display in several outlets and centers of SMEs.

\subsection{Omah Duren Surabaya Accounting Process}

Basically, the owner feels that the accounting has an important role, because it will gives her a reference to see the profits derived from the capital. "The benefit of recording is to find out how many percent of our capital that become the profit of the business is.." Because of the importance of recording to the owner of Omah Duren, every month the owners record the income and expenditure from recapture of proofs on the purchase of raw materials, equipment production, and product sales.

\subsubsection{Transaction Recording Process}

It is a important that every financial transaction must be accompanied by receipts. These receipt is one of accountability sources as a proofs that those specific transaction has been done. There are some transaction proofs that used as the basis for recording by Omah Duren while conducting its operational activities. Receipt for printing of packaging sticker, notes on purchasing including the purchase of raw materials (durian meat and bubble). 


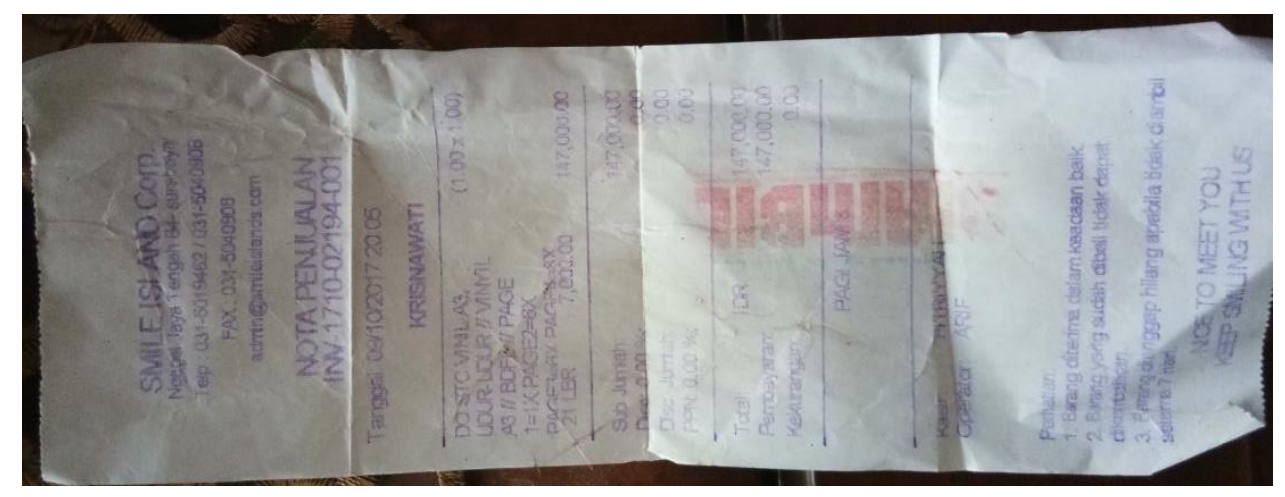

Picture 4 Receipt for Packaging Striker

In addition to raw materials, the purchase of packaging bottles should also get a purchase note, but sometimes the owner did not get it. Receipt evident for merchandise delivery, this evident is obtained from the delivery of merchandise to outlets and day care of SMEs center, because while delivery of goods, Omah Duren does not immediately get cash money.
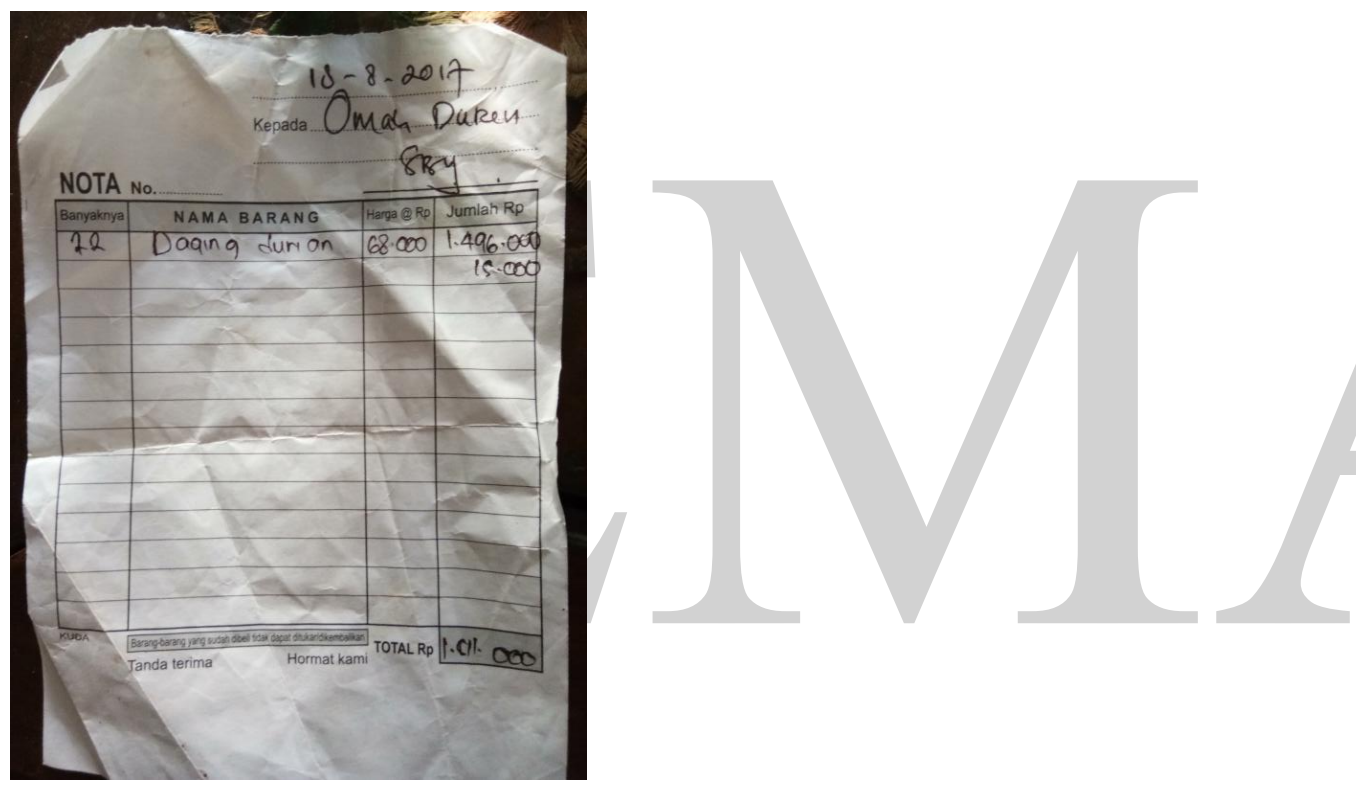

\section{Picture 5 Durian Receipt Notes}

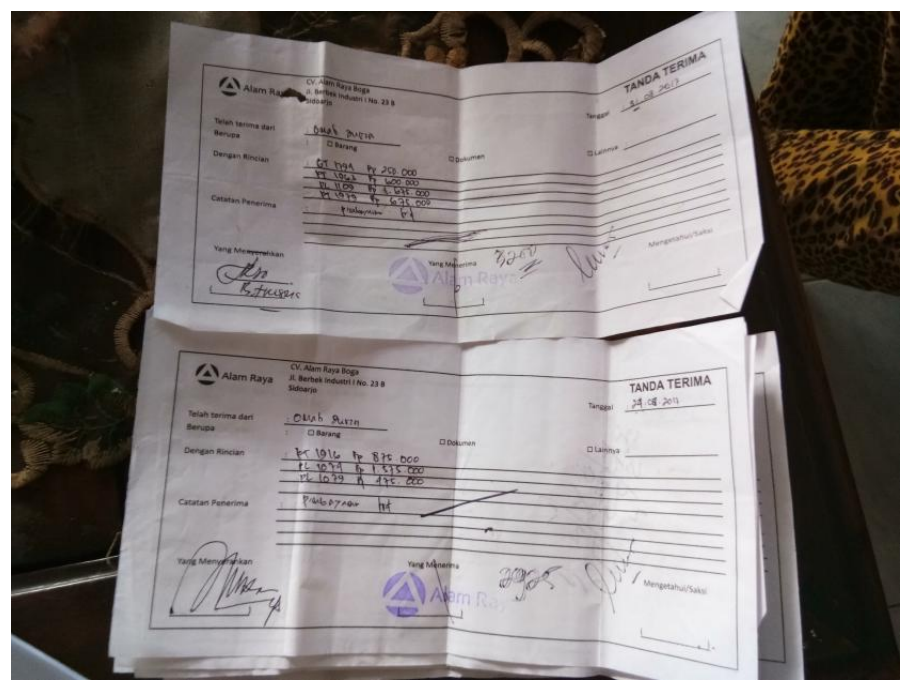

Picture 6 Merchandise Delivery Notes Proof 
Receipt on refueling the gas usually obtained when refueling in Pertamina Station. Bank transfer evident are included funds receipt on product sales and credit card installment payments. The proceeds from the sale of products are obtained from offline and online transactions to Omah Duren. Triple note is a note provided by Omah Duren for direct purchases and online purchases. Direct purchase means the buyers who order directly to the owner in large quantities. The first sheet (white color) will be given to the consumer, while the other two (red and green) are archived by the owner.

Not all occurrence transactions get transaction evident, for example the purchase of raw materials in the form of drinking water, sugar, and milk because the owner bought them in a shop near the house, then she do not get any evidence such as a note or receipt. Thus, the owner will keep a record even if there is no proof of the transaction, as raw material prices remain stable, making it easier for the owner to calculate the expenses incurred on the item. From the evidence of the transaction, Omah Duren classifies it into accounts which will then be recorded and reported. The accounts that can be seen as follows :

a. Cash account

Cash is a deposit in bank, bank account used is the owner's account Bank of BCA as the main account and Bank Mandiri if necessary. Because sales transactions not always use cash, it will be withdrawn when the owner makes a purchase for the production process.

b. Raw material expense

Raw material expense is the burden of purchasing durian meat, milk, drinking water, bubble, and sugar.

c. Administrative expenses

Administrative expenses are purchase of triple note and sticker printing.

d. Other expenses

Transport costs are classified by owner as other expenses, as she/he considers transportation expenses exclude the production costs. "Transportation does not use bon-bon, the calculation is included with others such as for gasoline and others. It means taken from the global." In addition, the transportation is not devoted to the delivery of goods to consumers, but private property. Transportation expenses include in the purchasing of Fuel (BBM) for motorcycles and cars.

e. Prive

Prive is the amount of cash from the operational results taken by the owner for his personal use. Prive taken amounted to total profit from the sale, and considered as salary for the owner as an exchange for production employees.

From the classification of existing accounts, the accounts are grouped into income and expenses. "I make it simple and easy, so all income transactions made into one, expenditure made into one, income and expenditure, that's all." The income and expenditure are separated into two parts in a basic journal, in which the entry column is on the left as a debit and expenditure on the right as a credit. The income column contains an account that adds cash, which is recorded as cash. The revenue usually comes from sales. Expenditure column that contain cash-out accounts such as raw material costs, administrative costs, other fees, and prizes.

\subsubsection{Recording and Reporting Process}

Recording and reporting performed by Omah Duren begins with the collection of evidence related to transactions that occurred. Certificate of transaction evidence is unified when the owner performs the recording. The transaction recording is done in a manual book by the owner. But unfortunately, sometimes the purchase notes are not stored well, so sometimes folded, even when the owner doing the recording required notes is lost. So, the recording process is done based on the amount remembered by owner. Records are made using the cooperative bookkeeping system, where the income and expenditures are totaled, then the difference will be used as capital for the next 
month, she said "Bookkeeping only for in and out of income expenditure and credit disbursement. And then total balance, below is cash for the beginning of the month, zero again, such in cooperative bookkeeping."

Transactions recorded are transactions for a month from the recapitulation of transactions evident and transactions without evidence. Accounting method applied is cash basis, i.e. where receipts are recorded when cash is received and expenditures are recorded when cash is incurred, i.e. when payment of fees. The owner will record the cash receipts when the cash is actually received, that is, when the buyer transfers funds on the purchase of merchandise to the owner's bank account through the evident of transfer given to the owner. Funds are transferred every two weeks, meaning that the funds transferred are the total of two transactions for a month. Expenditures will be recorded on cash disbursements, in example when cash is actually issued, when the owner buys raw materials, packing bottles, until paying for expenses such as administrative expenses, and other expenses. Transportation expenses, such as Petroleum Fuel are included in Other Expense accounts. For the owner of Omah Duren, recording is performed only to analyze whether the expenditure does not exceed the capital, in order to see profit earned in a month. Like the owner's statement as follows: "the benefit of recording is to find out profit of our business and what percentage from our capital."

\subsection{The Challenges and Solutions in Implementing Basic Accounting Process in Omah Duren Surabaya}

Recording and reporting of SMEs Omah Duren is still inadequate, so it still faces various problems that arise. Adequate according to Big Indonesian Dictionary (KBBI) is to meet (requirement, desire), sufficient. In this case, it is adequate to meet the standards, such as PSAK. The owner makes insufficient recording system implemented in Omah Duren, this is due to the lack of knowledge about the correct and generally accepted accounting system. Beside the lack of accounting knowledge, other obstacles faced are the views on the complexity of the accounting system that must be recorded both in terms of revenue and expenditure in detail, which are still unacceptable. The recording and reporting that have been applied impacts on the rise of some problems like :

a. The accuracy in planning annual/monthly budgeting

Omah Duren has a monthly budgeting indirectly (it can be seen from the owner's record). The recording made turn into a reference to see the profits derived from the capital issued by the owner, she said "the benefit of recordings is to find out the profits of the business, how much the percentage of our capital." Bussines owners made a budgeting in order to maintain their production cost and gained more revenue. Although, this effort is good, but is not enough, because the owner does not take the net profit into account, which means there are nonoperational expenses that have not been taken into account in reducing revenue, there is possibility that income could not cover fixed costs. Researcher added that the owner needs to make an inventories budgeting too. Inventories consist of raw materials, bottles packaging, and finished products should always be monitored at all times, in order to avoid excess inventory and calculated the storage capacity.

b. The calculation of production cost

The calculation of production cost is counted once at the beginning of selling price. At that time, the calculation of the cost production and selling price is done on a merely basis. The calculation of selling price of the product is based on the raw material plus the mark up with not all expenses that affecting production process is included in the calculation. From the grouping of accounts conducted by Omah Duren, through observation and interviews results, researcher founded that there are an expenses that are not recorded such as the installment of fixed assets, interests of fixed assets, utility expenses, such as water and electricity expenses, depreciation expenses for machinery and vehicles. There are expenses is still not recognized 
as expense, for example, the water and electricity expenses. Because the production place also the owner home, it will be difficult to determine how much operational (cost of production) expenses should be paid, especially on the use of blenders and freezers. The effort in separating between the operational and non-operational activities is quite inconvenient for the owner. Therefore, this expense is not included in the calculation of expenditures and cost of goods sold. There are several ways that can be done by the owner to solve the problem like providing his own assumptions about electricity and water used. For example, the use of electricity in a month is $2 / 10$ of a few $\mathrm{kWh}$, then the owner just multiply the result at a price per $\mathrm{kWh}$. This classification of costs is determined on the basis of the objectives to be achieved (Mulyadi, 2010). This report can be used to calculate the expense that should be borne by Omah Duren in a month. So it can be estimated how much the expense of the specific responsibility in a month. The benefits of making/calculating cost of production by Mulyadi (2010) is to determine the selling price of the product, monitor the realization of cost production, calculate the periodic profit and loss, and determine the cost of raw materials, and finished product inventories that presented in the balance sheet. In the balance sheet, the owner must present the cost of raw materials inventory and the price of the finished product at the balance sheet date.

c. There is no inventory calculation Inventories such as raw materials, finished products and packaging bottles have not been applied in inventory calculations like the calculation the beginning of inventory and ending inventory both raw materials, packaging bottles and finished goods. Omah Duren added their raw materials and packaging inventory based on the owner predictions, if the inventory stock is reducing, the owner will immediately order or buy it. Therefore researcher said that its better for the owner to use inventory card as a helper to recap the inventory, so he/she does not have to make any more estimation. Picture 8 is an example of inventory card that can be applied at Omah Duren. Although the owner has applied this inventory card, do regularly control process is important. Periodically re-check can reduce human errors from writing numbers/dates. This re-check activities will be more efficient by using a inventory card, as there is a possibility that the owner forgets about the amount of its inventory due to the lack of inventory recording. 


\section{Omah Duren}

Cost of Goods Manufactured Scheduled

For the month ending January, 31, 2017

Purchases and Costs

Materials

Beginning Inventory $\quad$ xxx

Purchases : Raw Materials $\quad \mathrm{xxx}$

Purchase Return

$(\mathrm{xxx})$

Total Materials

$\mathrm{Xxx}$

Ending Inventory

$\mathrm{XXX}$

Total Used Materials

$\mathbf{X x x}$

Packages

Initial Purchase

$\mathrm{XXX}$

Purchases : Packages

$\mathrm{XXX}$

Purchase Return

$(\mathrm{XXX})$

Total Packages

XXX

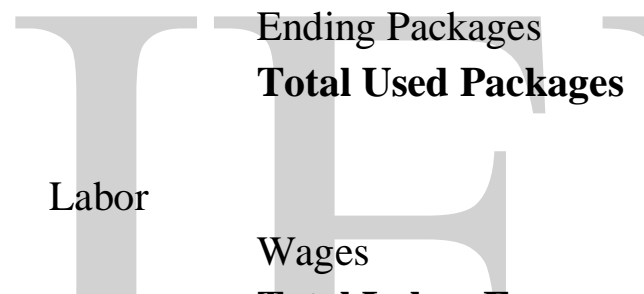

XXX

Total Labor Expenses

Total Labor Expenses

Cost of Production

Water and Electricity

Depreciation-Building

Depreciation -Freezer

Depreciation -Blender

Depreciation -Cup Sealer

$(\mathrm{xxx})$

Total Cost of Production

$(\mathbf{x x x})$

\section{Total Cost}

$\mathbf{X X X}$

Finished Goods

Beginning of Finished Goods
Inventory
Processed of Finished Goods
Finished Goods
Total Finished Goods

XXX 


\section{Omah Duren}

Inventory Card

Product Name

Product Code

\begin{tabular}{|c|c|c|c|c|c|c|}
\hline No & Date & Detail of Information & Input & Output & Amount & Signature \\
\hline & & & & & & \\
\hline & & & & & & \\
\hline & & & & & & \\
\hline & & & & & & \\
\hline & & & & & & \\
\hline & & & & & & \\
\hline & & & & & & \\
\hline & & & & & & \\
\hline & & & & & & \\
\hline & & & & & & \\
\hline & & & & & & \\
\hline & & 1 & & & & \\
\hline & & & & & & \\
\hline & & & & & & \\
\hline & & & & & & \\
\hline & & & & & & \\
\hline 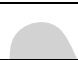 & & 7 & & & & . \\
\hline & & 7 & 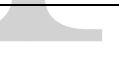 & 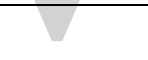 & & 2 \\
\hline & & & & & & \\
\hline
\end{tabular}

Picture 8 Inventory Card

d. Inappropriate Account Coding

Omah Duren has a lack account classification because there are some accounts that have not been entered. So, before creating financial statements, it is necessary to identify accounts used to accommodate transactions that occur on related accounts. These accounts are grouped into five parts, (1) for assets, (2) for liabilities/debt, (3) for equity, (4) for income and (5) for expenses. Picture 9 is an example of accounts classification for Omah Duren. Each business has different accounts classification. The advantages in using accounts coding are as follows.

1. The accounts classification can become more organized and systematic.

2. The control of corporate transactions process become effectively.

3. Facilitating the subsequent data processing resulting in financial statements and in accordance with the need for control.

4. Analyzing of company's financial situation becomes more organized and systematic. 


\begin{tabular}{|c|c|c|c|}
\hline Code & Account Name & Code & Account Name \\
\hline 1 & Asset & 3 & Equity \\
\hline 1.1 & Curent Asset & 3.1 & Owner Equity \\
\hline 1.1 .1 & Cash & 3.2 & Prive \\
\hline 1.1 .1 .1 & Cahs in Bank & 3.3 & Retain Earning \\
\hline 1.1.1.1.1 & Bank BCA & & \\
\hline 1.1.1.1.2 & Bank Mandiri & 4 & Revenue \\
\hline 1.1.1.2 & Cash on Hand & 4.1 & Sale of Premium $250 \mathrm{ml}$ \\
\hline 1.1 .2 & Account Receivable & 4.2 & Sale of Premium 500ml \\
\hline 1.1 .3 & Inventory & 4.3 & Sale of Lite $250 \mathrm{ml}$ \\
\hline 1.1 .3 .1 & Raw Material & 4.4 & Sale of Lite $500 \mathrm{ml}$ \\
\hline 1.1 .3 .2 & Finished Goods & 4.5 & Other Revenue \\
\hline 1.1 .3 .3 & Bottle & & \\
\hline 1.2 & Non-Current Asset & 5 & Expense \\
\hline 1.2 .1 & Land & 5.1 & Cost of Merchandise Sold \\
\hline 1.2 .2 & Building & 5.1 .1 & Cost of Merchandise Sold \\
\hline 1.2 .2 .1 & Building & 5.1 .2 & Sales Return \\
\hline 1.2.2.2 & Acc Depreciation-Building & 5.1 .3 & Sales Discount \\
\hline 1.2 .3 & Equipment & 5.2 & Operational Expense \\
\hline 1.2.3.1 & Freezer & 5.2 .1 & Salary Expense \\
\hline 1.2.3.2 & Acc Depreciation -Freezer & 5.2 .2 & Utilities Expense \\
\hline 1.2.3.3 & Blender & 5.2 .3 & Office Supplies Expense \\
\hline 1.2 .3 .4 & Acc Depreciation -Blender & 5.2 .4 & Delivery Expense \\
\hline 1.2 .3 .5 & Cup Sealer & 5.2 .5 & Marketing Expense \\
\hline 1.2 .3 .6 & Acc Depreciation -Cup Sealer & 5.2 .6 & Depreciation of Building Exp \\
\hline 1.2 .4 & Vehicle & 5.2 .7 & Depreciation of Freezer Exp \\
\hline 1.2 .4 .1 & Car & 5.2 .8 & Depreciation of Blender Exp \\
\hline 1.2.4.2 & Acc Depreciation-Car & 5.2 .9 & $\begin{array}{l}\text { Depreciation of Cup Sealer } \\
\text { Exp }\end{array}$ \\
\hline 1.2.4.3 & Motor Cycle & 5.2 .10 & Depreciation of Car \\
\hline 1.2.4.4 & Acc Depreciation -Motor Cycle & 5.2 .11 & Depreciation of Motor Cycle \\
\hline & & 5.2 .12 & Other Expense \\
\hline 2 & Liabilities & 5.3 & Non-Operational Expense \\
\hline 2.1 & Current Liabilities & 5.3 .1 & Installment \\
\hline 2.1 .1 & Notes Payable & 5.3 .2 & Bank Administration \\
\hline 2.1 .2 & Account Payable & & \\
\hline 2.1 .3 & Other Account Payable & & \\
\hline 2.2 & Non-Current Liability & & \\
\hline 2.1 .1 & Long Term Notes Payable & & \\
\hline
\end{tabular}

Picture 9 Account Code 


\section{Omah Duren}

Financial Position Statement

For the month ending December, 31, 2017

\section{Asset}

1.1 Current Asset

1.1.1 Cash

1.1.1.1 Cash in Bank

1.1.1.1.1 Bank BCA

1.1.1.1.2 Bank Mandiri

1.1.1.2 Cash on Hand

1.1.2 Account Receivable

1.1.3 Inventory

1.1.3.1 Raw Material

1.1.3.2 Finished Goods

1.1.3.3 Bottle

Total Current Asset

$1.2 \quad$ Non-Current Asset

1.2.1 Land

1.2.2 Building

1.2.2.1 Building

1.2.2.2 Acc Depreciation-Building $\mathrm{xxx}$

1.2.3 Equipment

1.2.3.1 Freezer

1.2.3.2 Acc Depreciation-Freezer

1.2.3.3 Blender

1.2.3.4 Acc Depreciation -Blender $\mathrm{xxx}$

1.2.3.5 Cup Sealer $\quad \mathrm{xxx}$

1.2.3.6 Acc Depreciation-Cup Sealer xxx

1.2.4 Vehicle

1.2.4.1 Car

1.2.4.2 Acc Depreciation-Car $\quad \mathrm{xxx}$

1.2.4.3 Motorcyle $\quad \mathrm{xxx}$

1.2.4.4 Acc Depreciation - $\quad$ xxx

Motorcycle

\section{Total Non-Current Asset}

\section{Total Asset}

Picture 8 Statement of Financial Position

\section{Liabilities}

\subsection{Current Liabilities}

2.1.1 Notes Payable $\quad x x x$

2.1.2 Account Payable $\mathrm{xxx}$

2.1.3 Other Account Payable xxx Total Current Liabilities $\quad$ xxx

\subsection{Non Current Liabilities}

2.1.1 Long Term Notes Payable xxx Total Non Current $\quad$ xxx

\section{Liabilities}

Total Liabilities

$\mathbf{X X X}$

Xxx Equity

3.1 Owner Equity $\quad \mathrm{xxx}$

3.2 Prive $\quad \mathrm{xxx}$

3.3 Retained Earning $\quad \mathrm{xxx}$ Total Equity $\quad \mathbf{x x x}$

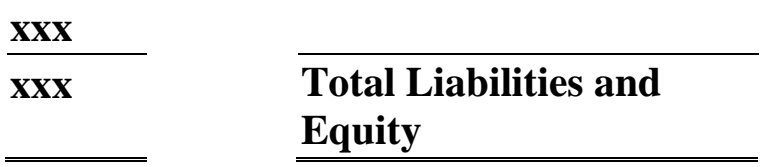




\section{Omah Duren}

Income Statement

For the month ending December, 31, 2017

\begin{tabular}{ll}
\hline \hline & Income Statement \\
4.1 & Sales of Premium $250 \mathrm{ml}$ \\
4.2 & Sales of Premium $500 \mathrm{ml}$ \\
4.3 & Sales of Lite $250 \mathrm{ml}$ \\
4.4 & Sales of Lite $500 \mathrm{ml}$ \\
5.1 .2 & Sales Return \\
5.1 .3 & Sales Discount \\
& Net Sales \\
\hline
\end{tabular}

$\mathrm{xxx}$
$\mathrm{xxx}$
$\mathrm{xxx}$
$\mathrm{xxx}$
$(\mathrm{xxx})$
$(\mathrm{xxx})$

5.1.1 Cost of Manufactured Sold

$(\mathrm{xxx})$

\section{Gross Profit}

$\mathbf{X x X}$

5.2 Operational Expense

$\begin{array}{lll}\text { 5.2.1 } & \text { Salary Expense } & (\mathrm{xxx}) \\ 5.2 .2 & \text { Utilities Expense } & (\mathrm{xxx}) \\ 5.2 .3 & \text { Office Supplies Expense } & (\mathrm{xxx}) \\ 5.2 .4 & \text { Delivery Expense } & (\mathrm{xxx}) \\ 5.2 .5 & \text { Marketing Expense } & (\mathrm{xxx}) \\ 5.2 .6 & \text { Depreciation of Building Exp } & (\mathrm{xxx}) \\ 5.2 .7 & \text { Depreciation of Freezer Exp } & (\mathrm{xxx}) \\ 5.2 .8 & \text { Depreciation of Blender Exp } & (\mathrm{xxx}) \\ 5.2 .9 & \text { Depreciation of Cup Sealer Exp } & (\mathrm{xxx}) \\ 5.2 .10 & \text { Depreciation of Car } & (\mathrm{xxx}) \\ 5.2 .11 & \text { Depreciation of Motor Cycle } & (\mathrm{xxx}) \\ & \quad \text { Total Operational Exp } & \end{array}$

\section{Operational Revenue}

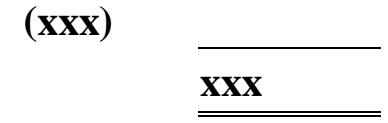

Other Revenue and Expense

\section{$4.5 \quad$ Other Revenue}

$5.3 \quad$ Non Operational Expense

5.3.1 Installment (xxx)

5.3.2 Bank Administration ( $\quad$ (xxx)

$5.4 \quad$ Other Expenses (xxx)

Total Expenses

Total Other Revenue and Expenses

$(\mathbf{x x x})$

$\mathbf{X X X}$

\section{Net Income}

$\mathbf{X X x}$

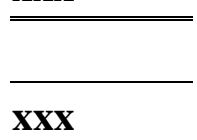

Picture 9 Income Statement 
Picture 9 describes revenues that received by the company during a certain period as well as the costs that incurred to obtain the revenue (Harahap, 2006). This report provide an information of net income/loss that earned in a specific period and used to measure business sales performance.

\section{Omah Duren}

Statement of Changes in Equity

For the month ending December, 31, 2017

\begin{tabular}{lll}
\hline \hline Trisna's Equity, Dec, 1,2017 & $\mathbf{x x x}$ \\
Investment (monthly) & $\mathrm{Xxx}$ & \\
Net Income in December & $\underline{\mathrm{Xxx}}$ \\
\cline { 2 - 3 } & $\begin{array}{l}\mathbf{X x x} \\
\text { (xxx) }\end{array}$ \\
Prive & & $\underline{\mathbf{X x x}}$ \\
Changes in Equity & $\underline{\mathbf{X x x}}$ \\
Trisna's Equity, Dec, $\mathbf{3 1 2 0 1 7}$ & &
\end{tabular}

Picture 10 Change Equity Statement

Picture 10 serves as a means of information on net assets (assets - liabilities) in a certain period of change in the composition of equity/capital of business owners. End capital of the period will be the initial capital for the next period.

\section{Omah Duren}

Cash Flow Statement

For the month ending December, 31, 2017

Cash Flow from Operating Activities

Cash Receiot from Consumer

Cash Paid for Operating Cost

Cash paid to Creditors

\section{Net Cash Used in Operating Act}

$\mathrm{xxx}$

$(\mathrm{xxx})$

$(\mathrm{xxx})$

$\overline{\mathbf{x x x}}$

Cash Flow from Investing Activities

Fixed Asset Received

$\mathrm{XXX}$

Purchase of Fixed Asset

$(\mathrm{xxx})$

Short Term Investment Received

$\mathrm{XXX}$

Short Term Reinvesting

(XXX)

\section{Net Cash Used in Investing Act}

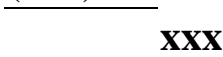

Cash Flow from Financing Activities

Owner Investment Received

XXX

Prive

$(\mathrm{xxx})$

Adding of Debt - Bank

$\mathrm{XXX}$

Payment of Debt - Bank

Net Cash Used in Financing Act

Cash and Cash Equivalent at Dec, 312017

(XXX)

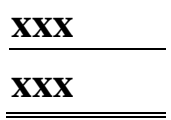

Picture 11 Cash Flow Statement 
Picture 11 shows cash receipts and disbursements during a certain period. This report is useful in evaluating cash flows that is arising from operating, investing and financing activities per period and as an information in knowing the ability of company paying their debts and generating cash. Financial reports have interrelationships one with another. From the four reports above, it can be described as follows.
a. Net income in the Income Statement will be Net Income in Equity Changes Statement in December.
b. Trisna's Capital of December 31, 2017 in Equity Changes Statement will be balance of Owners' Equity Changes Statement of Financial Position.
c. Total Increase in cash and cash balances of December 31, 2017 in the Cash Flow Statement will be the Cash Balance at the Bank (BCA) in the Financial Position Statement.

\subsection{The Role of Recording and Reporting of Basic Accounting Implementation in Omah Duren Surabaya}

Recording and reporting system provides a role in measuring revenue and operating expenses through cash receipts and cash expenditures. Recording and reporting by Omah Duren is limited due to the owners need to analyze receipts and expenditures, therefore she designed they own accounting system only based on her interest. Omah Duren needs to make changes to get an adequate system in recording and reporting their business activity. Researcher recommends to Omah Duren to extent their accounting system capability, so they can obtain more accounting information (rather than just expenditures and income information). Even each company has an uncertain position to get all the benefits of accounting due to the different perspectives of the financial statements presented, but in general, the role of accounting at least can help business owner knows their profit and losts, determining the selling price, and as an input in making consideration of purchasing, business development, human resources extension, fixed asset extension, and getting financing from bank.

\section{RESEARCH CONCLUSION AND LIMITATION}

\subsection{Conclusion}

Based on the case study, recording and reporting of SME of Omah Duren is still inadequate, so it still faces various problems arising from the perception of the owner as the recording system maker in Omah Duren. The problem faced by Omah Duren is the inaccurate of annual/monthly budget planning, not having an appropriate cost of goods manufactured calculation, still not doing inventory calculations, inappropriate account classification, and doesn't have financial statements. Therefore, it is better for the owner of Omah Duren to calculate their Cost of Production by making the report of cost of gooed manufactured, inventory card, performing an adequate account classification, making general financial statements such as financial position statement, income statement, changes in equity statement, and cash flow statement. The proper recording and reporting process can be bases for the business in knowing the advantages or disadvantages, the bases for determining the selling price of the product, as an input in making decision for purchasing some inventory, business development, human resources extent and additional of fixed business assets, and facilitate the application of financing to the bank. Through this research, it is expected to provide benefits for Omah Duren in creating adequate records to provide benefits for the continuity of SMEs business in the future. This research also expected to solve recording and reporting issues that exist in Omah Duren. Researcher also hope that this paper is useful for academics and general readers, in order to be used as a reference for writing in the future learning about the application of accounting on SMEs, as well as increases the knowledge about the role of basic accounting toward SMEs existence. 


\subsection{Limitation}

This study only focused in Omah Duren Surabaya as the research object. Therefore, researcher recommended for future study to consider the type of SMEs Business in extending the role of basic accounting in any type of SMEs Business.

\section{REFERENCES}

Afrianto, D. (2016). Dalam 5 Tahun, UKM di Surabaya Tumbuh 300\%. Retrieved from https://economy.okezone.com/read/2016/02/24/320/1320538/dalam-5-tahun-ukm-disurabaya-tumbuh-300.

Chandra, A. A. (2016). Risma: Dulu Ada 92 UKM di Surabaya, Sekarang 3.000 Lebih Sri Mulyani Dorong Forum Ekonomi Syariah Global Danai UMKM. Retrieved from https://finance.detik.com/berita-ekonomi-bisnis/3149875/risma-dulu-ada-92-ukm-disurabaya-sekarang-3000-lebih.

Ediraras, D. T. (2010). Akuntansi dan Kinerja UKM. Jurnal Ekonomi Bisnis 2(15): 152-158.

Harahap, S. S. (2003). Teori Akuntansi, Edisi Kelima, Jakarta: PT. Raspindo.

Harahap, S. S. (2006). Analisis Kritis Atas Laporan Keuangan. Jakarta: Raja Grafindo Persada.

Ikatan Akuntansi Indonesia (IAI). (1994). Penyajian Aktiva Lancar dan Kewajiban Jangka Pendek. Pernyataan Standar Akuntansi Keuangan, PSAK No. 9. Jakarta: DSAK-IAI

Ikatan Akuntansi Indonesia (IAI). (1994). Pendapatan. Pernyataan. Standar Akuntansi Keuangan, PSAK No. 21. Jakarta: DSAK-IAI

Ikatan Akuntan Indonesia (IAI). (1999). Standar Akuntansi Keuangan. Jakarta: Salemba Empat.

Ikatan Akuntansi Indonesia (IAI). (2007). Aset Tetap. Pernyataan Standar Akuntansi Keuangan, PSAK No. 16. Jakarta: DSAK-IAI

Ikatan Akuntansi Indonesia (IAI). (2007). Akuntansi Ekuitas. Standar Akuntansi Keuangan, PSAK No. 21. Jakarta: DSAK-IAI

Ikatan Akuntansi Indonesia. (2009). Penyajian Laporan Keuangan. Pernyataan Standar Akuntansi Keuangan, PSAK No. 1. Jakarta: DSAK-IAI

Marta, M. F. (2016). UMKM dan Ketidakberdayaannya. Retrieved from http://bisniskeuangan.kompas.com/read/2016/06/09/084045026/umkm.dan.ketidakberdayaan nya

Mulyadi. (2010). Akuntansi Biaya. Yogyakarta: Unit Penerbit dan Percetakan Sekolah Tinggi Ilmu Manajemen YKPN.

Nawawi, H. \& Martini H. (1992). Instrumen Penelitian Bidang Sosial. Yogyakarta: Gadjah Mada University Press.

Nazir, M. (1988). Metode Penelitian. Jakarta: Ghalia Indonesia.

Pamungkas, P. T. (2015). Pengaruh Modal, Kualitas Sumber Daya Manusia (SDM) dan Promosi Terhadap Pemberdayaan UMKM. Semarang: Universitas Pandanaran Semarang. 
Pinasti, M. (2007). Pengaruh Penyelenggaraan dan Penggunaan Informasi Akuntansi Terhadap Persepsi Pengusaha Kecil atas Informasi Akuntansi: Suatu Riset Eksperimen. Simposium Nasional Akuntansi X. Makasar.

Primadhtya, S. (2016). Sri Mulyani Dorong Forum Ekonomi Syariah Global Danai UMKM. Retrieved from https://www.cnnindonesia.com/ekonomi/20160802124607-92-148603/srimulyani-dorong-forum-ekonomi-syariah-global-danai-umkm/.

Sugiyono. (2012). Memahami Penelitian Kualitatif. Bandung: ALFABETA.

Suroto, P. (2016). Usaha Mikro Indonesia Makin Mengenaskan. Retrieved from http://www.berita9.com/pojok/usaha-mikro-indonesia-mengenaskan.html.

Undang-Undang No. 20 Tahun 2008 tentang Usaha Mikro, Kecil, dan Menengah.

Warren, C. S., Reeve, J. M., Duchac, J. E., Suhardianto, N., Kalanjati, D. S., Jusuf, A. A., \& Djakman, C. D. (2014). Accounting Indonesia Adaption 25th Edition. Jakarta: Salemba Empat.

*) Fauziah, University of Surabaya, Surabaya, Indonesia (E-Mail: lucyaerlinda@gmail.com)

*) Fauziah, University of Surabaya, Surabaya, Indonesia (E-Mail: stefanie.gianto@gmail.com) 